\title{
A Review of the Role Portrayed by Vitamin D in Cancer
}

\author{
Rakesh Dhankhar ${ }^{1}$, Kiran Dahiya ${ }^{2 *}$, Raunak Ahlawat ${ }^{3}$, Priya Dahiya ${ }^{4}$, Sunder Singh ${ }^{1}$ and Keerti Gupta ${ }^{2}$ \\ ${ }^{1}$ Department of Radiotherapy, Pt. BD Sharma PGIMS, Rohtak, Haryana, India \\ ${ }^{2}$ Department of Biochemistry, Pt. BD Sharma PGIMS, Rohtak, Haryana, India \\ ${ }^{3}$ Ex-student, BPSGMCW, Khanpur Kalan, Sonepat, Haryana, India \\ ${ }^{4}$ Department of Obstetrics and Gynecology, Rajshree Medical Research Institute, Bareilly, Uttar Pradesh, India
}

Submission: May 07, 2018; Published: June 25, 2018

"Correspondence Address: Kiran Dahiya, Professor, Department of Biochemistry, Pt. BD Sharma PGIMS, Rohtak, Haryana, India, Tel: 9896111985; Email: kirandahiya_2002@yahoo.com

Abstract

Vitamin D, also known as calcitriol, is not only one of the fat soluble vitamins but is a versatile hormone. Besides taking part in calcium homeostasis in the body and taking care of the bone health, it performs a number of important functions in the body. It can be synthesized by the body in presence of sunlight as well as can be derived from few dietary sources. Recently it has been observed that deficiency of vitamin D is rampant in general population around the world. Deficiency of vitamin D $\left[1,25-(\mathrm{OH})_{2} \mathrm{D}_{3}\right]$ has now been associated with a variety of clinical diseases including cancer. Though the exact mechanism involved is not clear yet, a number of theories have been put forward for the role played by vitamin $\mathrm{D}$ in protection against cancer. For this effect, important actions include anti-inflammatory, anti-proliferative, anti-angiogenic and pro-apoptotic which are able to abet cancer at any stage. Anti-cancer action of vitamin D is seen in prevention of all the stages of carcinogenesis. It helps to improve the efficacy of chemotherapy as well as radiotherapy in the treatment while helping in minimizing or avoiding the adverse effect associated. But further research is still needed to establish all the claims.

Keywords: Vitamin D; Anti-cancer activity; Anti-proliferative; Anti-inflammatory; Pro-apoptotic; Radiosensitization

\section{Introduction}

There is a recent surge in the interest of estimating, analyzing and associating vitamin $\mathrm{D}$ deficiency with a variety of clinical disorders. Vitamin D, a fat-soluble vitamin, is considered a prohormone because the body can synthesize vitamin D from its precursor (cholesterol) when exposed to ultraviolet light at a wavelength between 290-315 nm. Active form of vitamin D is 1,25-dihydroxy cholecalciferol/ 1,25-dihydroxy vitamin $\mathrm{D}_{3}$ $\left[1,25-(\mathrm{OH})_{2} \mathrm{D}_{3}\right]$ or calcitriol. This metabolite interacts with its ubiquitous nuclear vitamin $\mathrm{D}$ receptor (VDR) to regulate the transcription of a wide spectrum of genes involved in calcium and phosphate homeostasis as well as in cell division and differentiation. It is these latter actions that have attracted tumor biologists to explore the effects of vitamin $\mathrm{D}$ and to use it as an antiproliferative agent in cancer cells in vitro and in vivo [1]. Adequate circulating levels of active form of this vitamin need to be maintained for normal functioning of all the systems of the body irrespective of age and gender. Insufficient levels of vitamin D may affect any system and produce the related clinical abnormality [2].

Lately, the scientific evidence is accumulating to demonstrate the insufficiency of vitamin D globally. Factors, which play a crucial role in the worldwide prevalence of vitamin D insufficiency, vary among countries; but in all cases involve limitations in either or both cutaneous synthesis and dietary sources of vitamin D. A rough estimate indicates that about 1 billion people globally are vitamin $\mathrm{D}$ deficient and vitamin $\mathrm{D}$ deficiency is quite common in regions and countries including North America, Northern Europe, Saudi Arabia, United Arab Emirates, Australia, Turkey, India and Lebanon [3] Besides the regulation of calcium and phosphorus levels in the body, a variety of diverse functions have been assigned to vitamin D. Therefore, its deficiency is bound to be implicated in a number of clinical chronic disorders like heart disease, bone disorder, cancer, infectious, inflammatory and autoimmune diseases, inflammatory bowel disease, multiple sclerosis, rheumatoid arthritis and type-I diabetes mellitus etc. [3]. Many mechanisms have been put forward for its role in causation of different disorders but this review has been targeted to throw some light on the association between vitamin D deficiency and development of cancer. The general aspects pertaining to its metabolism and assessment will be discussed first.

\section{Discussion}

\section{Metabolism of vitamin D}

The major sources for vitamin D include sun exposure (predominant source), foods like fatty fish, beef liver, cheese, 
egg yolk, cod liver oil and mushrooms etc. [4] Vitamin $\mathrm{D}_{3}$ can be synthesized in the skin from the precursor 7-dehydroxycholesterol or be derived in the form of vitamin $\mathrm{D}_{3}$ or vitamin $\mathrm{D}_{2}$ (collectively known as vitamin D) from dietary sources. Vitamin D and its metabolites are mostly hydrophobic and thus require a protein (vitamin D-binding protein) for their transport in the aqueous environment of the bloodstream to sites of storage (adipose tissue) or sites of activation (liver and kidney) or sites of action. Vitamin D undergoes its first step of activation with help of 25-hydroxylase to produce 25-hydroxy vitamin $\mathrm{D}_{3}$ in the liver, a step carried out by both liver mitochondrial (CYP27A1) and microsomal cytochrome P450 isoforms CYP2R1,CYP3A4, and CYP2J3 [5-7].

The circulating metabolite, 25-hydroxyvitamin $\mathrm{D}_{3}$, is activated to the hormonal form, $1,25-(\mathrm{OH})_{2} \mathrm{D}_{3}$, primarily in the kidney. Patients with chronic renal failure exhibit frank rickets or osteomalacia due to a deficiency of circulating $1,25-(\mathrm{OH})_{2} \mathrm{D}_{3}$ caused by lack of renal $1 \alpha$-hydroxylase $[8,9]$. The main component of the $1 \alpha$-hydroxylase enzyme is the cytochrome P450, CYP27B1, which is strongly down-regulated by its product, $1,25-(\mathrm{OH})_{2} \mathrm{D}_{3}$ and up-regulated by parathyroid hormone (PTH) as part of the calcium homeostatic loop and up-regulated by fibroblast-like growth factor 23 as part of the phosphate homeostatic loop $[10,11]$.

\section{Assessment of vitamin D Levels}

Though $1,25(\mathrm{OH})_{2} \mathrm{D}_{3}$ is the active form of vitamin $\mathrm{D}$ but $25(\mathrm{OH})$ $\mathrm{D}_{3}$ is the predominantly analyzed form. It is because of the fact that serum $25(\mathrm{OH}) \mathrm{D}_{3}$ is the major circulating form of vitamin $\mathrm{D}$ and has a half-life of 2 to 3 weeks compared with $1,25(\mathrm{OH})_{2} \mathrm{D}$, which has a circulating half-life of 4 hours and a concentration 1,000 times lower than that of 25(OH)D. Besides, vitamin D deficiency is associated with a compensatory increase of PTH secretion, which stimulates the kidneys to produce more $1,25(\mathrm{OH})_{2} \mathrm{D}_{3}$. Thus, when $25(\mathrm{OH}) \mathrm{D}_{3}$ levels fall due to vitamin $\mathrm{D}$ deficiency, the concentrations of $1,25(\mathrm{OH})_{2} \mathrm{D}_{3}$ may remain within normal limits and in some cases, they might even be elevated. In suspected renal impairment and inherited disorders of $25(\mathrm{OH}) \mathrm{D}_{3}$ and phosphate metabolism, both $25(\mathrm{OH}) \mathrm{D}_{3}$ and $1,25(\mathrm{OH})_{2} \mathrm{D}_{3}$ should be measured. There are multiple assays available to measure $25(\mathrm{OH}) \mathrm{D}_{3}$ but with great variability in results. Therefore, treatment should target a goal above normal reference levels (Table 1 ) to ensure adequate levels of $25(\mathrm{OH}) \mathrm{D}_{3}$ [12-15].

Table 1: Reference range for vitamin $D$ [66].

\begin{tabular}{|c|c|}
\hline Normal vitamin D levels & $30-100 \mathrm{ng} / \mathrm{mL}$ \\
\hline Vitamin D deficiency & $<20 \mathrm{ng} / \mathrm{mL}$ \\
\hline Vitamin D insufficiency & 21 to $29 \mathrm{ng} / \mathrm{mL}$ \\
\hline Vitamin D toxicity & $>100 \mathrm{ng} / \mathrm{mL}$ \\
\hline
\end{tabular}

\section{Vitamin $\mathrm{D}_{2}$ versus Vitamin $\mathrm{D}_{3}$}

The natural form of vitamin D in all animals and the form synthesizedin humanskin on exposure to sunlightis cholecalciferol, vitamin $\mathrm{D}_{3}$. Ergocalciferol (vitamin $\mathrm{D}_{2}$ ) is a synthetic product derived by irradiation of plant sterols / ergosterol. Initially, the two forms of the vitamin were considered to be interchangeable and equivalent, however, since the availability of the measurement of serum $25(\mathrm{OH}) \mathrm{D}_{3}$ as an indicator of vitamin D functional status, it has become clear that vitamin $\mathrm{D}_{2}$ is substantially less potent than vitamin $\mathrm{D}_{3}$. These two seem to be absorbed from the intestine and to be 25-hydroxylated in the liver with equal efficiency; however, vitamin $\mathrm{D}_{2}$ seems to up regulate several 24-hydroxylases, leading to increased metabolic degradation of both the administered $\mathrm{D}_{2}$ and endogenous $\mathrm{D}_{3}$. Thus, although it is certainly possible to treat patients satisfactorily with vitamin $\mathrm{D}_{2}$, ergocalciferol seems to have no advantage over vitamin $\mathrm{D}_{3}$ (cholecalciferol), which is the natural form of the vitamin and is less expensive [16-19].

\section{Vitamin D and Cancer}

Vitamin D deficiency is known principally for its association with bone disorders, but its newly recognized association with risk of several types of cancer is receiving considerable attention [20-22]. The high prevalence of vitamin D deficiency, combined with the discovery of increased risks of certain types of cancer in those who are deficient, suggests that vitamin D deficiency may account for several thousand premature deaths from colon, breast, ovarian and prostate cancer annually [23,24]. Vitamin D deficiency has been found to be associated with different stages of cancer. The vitamin D receptor (VDR) is essential to initiate various signaling pathways that are induced by $1,25(0 \mathrm{H}) 2 \mathrm{D}_{3}$ and have been shown to play a substantial role in its anticancer activity. There are several reports suggesting that VDR expression is gradually reduced when the stage of malignancy advances and certain VDR polymorphisms are associated with increased cancer risk $[25,26]$. It has also been reported that locally circulating $25(\mathrm{OH}) \mathrm{D}_{3}$ can be converted into $1,25(\mathrm{OH}) 2 \mathrm{D}_{3}$ by the enzyme 25 -hydroxyvitamin D-1 $\alpha$-hydroxylase (CYP27B1), which is not only expressed in kidney but in many other tissues such as colon, breast, prostate, placenta and different cells of the immune system suggesting the role played by these tissues in the metabolism of vitamin D [27]. The anti-cancer activities of $1,25(\mathrm{OH}) 2 \mathrm{D}_{3}$ include the effects of its local synthesis, which induces autocrine/ paracrine actions within the tumors as well as endocrine actions of circulating $1,25(\mathrm{OH}) 2 \mathrm{D}_{3}$ [28]. A number of molecular mechanisms have been put forward to demonstrate the association of vitamin $\mathrm{D}$ and cancer.

\section{Mechanisms for anti-cancer actions of vitamin D}

Various actions of vitamin D to contribute towards its anticancer property are as under:

\section{Anti-proliferative Actions}

In most cell types that express a functional VDR, exposure to $1,25(\mathrm{OH}) 2 \mathrm{D}_{3}$ results in the accumulation of cells in the G0/ G1 phase of the cell cycle. The transition from $G$ to S-phase is controlled by the pocket proteins retinoblastoma (Rb), p107 and p130. The phosphorylation status of these proteins determines their association with members of the E2F family of transcriptional 


\section{Cancer Therapy \& Oncology International Journal}

regulators that play a pivotal role in mediating gene expression during cell proliferation. In quiescent and early G1 cells, E2F4 and E2F5 act as transcriptional repressors by associating with p107 and p130. In proliferating cells, pocket proteins get phosphorylated and upon release by Rb, E2Fs 1-3 function as transcriptional activators inducing the transcription of target genes that regulate cell cycle progression. Dephosphorylation of $\mathrm{Rb}$ by $1,25(\mathrm{OH}) 2 \mathrm{D}_{3}$ results in the modulation of the expression and the activity of a number of genes. In general, activated cyclin/ cyclin dependent kinase (CDK) complexes phosphorylate $\mathrm{Rb}$ and a loss of their kinase activity generates hypo or dephosphorylated $\mathrm{Rb}$. Thus, both the expression of cyclins (D1, E, A) and CDKs $(2,4,6)$ can be decreased by $1,25(\mathrm{OH}) 2 \mathrm{D}_{3}[29,30]$.

The expression of the CDK inhibitors (CDKIs) p19, p21 and p27 are increased after treatment with $1,25(\mathrm{OH}) 2 \mathrm{D}_{3}$, and this effect is cell type specific. In different cancer cell lines, increased p27 protein levels are attained by secondary effects that increase the half-life of the protein. Vitamin D reduces phosphorylation of Thr187 residue of $\mathrm{p} 27$, which is important for its recognition by the ubiquitin-ligase SKP2 and rendering it less prone to degradation. The levels of protein SKP2 have also been found decreased by $1,25(\mathrm{OH}) 2 \mathrm{D}_{3}[30,31]$. It has also been reported that in HL60 cells, $1,25(\mathrm{OH}) 2 \mathrm{D}_{3}$ controls $\mathrm{p} 27$ levels by decreasing the expression of miR181s, a microRNA known to target p27 as well as regulating miR-106b expression to control p21 expression [32,33].

\section{Apoptosis}

Vitamin D can trigger the intrinsic, mitochondria-dependent pathway that induces cell death though the effect is not uniform for all types of cells. Depending on the cell type, 1,25(OH)2 $\mathrm{D}_{3}$ decreases the expression of the anti-apoptotic factors (Bcl-2, Bcl$\mathrm{XL}$ ) and increases the pro-apoptotic equivalents (Bax, Bak), thus, directing the cells towards apoptosis [34]. In prostate cancer (PCa) and breast cancer (BCa) cells, vitamin $\mathrm{D}$ activates the intrinsic pathway of apoptosis causing the disruption of mitochondrial function, cytochrome release and production of reactive oxygen species $[35,36]$. In some cells $1,25(\mathrm{OH}) 2 \mathrm{D}_{3}$ also directly activates caspases to induce apoptosis $[37,38]$. In addition, vitamin D analogues have been shown to enhance cancer cell death in response to radiotherapy and chemotherapy $[39,40]$.

\section{Inhibition of Tumour spread}

$1,25(\mathrm{OH}) 2 \mathrm{D}_{3}$ reduces the invasive and metastatic potential of many malignant cells as demonstrated in murine models of prostate and lung cancer by inhibiting angiogenesis [41]. The formation of new blood vessels is an important ability of malignant cells to guarantee their oxygen supply and tumor suppressors often interfere with this process. The mechanisms underlying this effect include the inhibition of angiogenesis and the regulation of the expression of key molecules involved in invasion and metastasis like the components of the plasminogen activator (PA) system and matrix metalloproteinases (MMPs), decreasing the expression of tenascin- $\mathrm{C}$, an extracellular matrix protein that promotes growth, invasion and angiogenesis, downregulation of the expression of $\alpha 6$ and $\beta 4$ integrins and increase in the expression of E-cadherin, a tumor suppressor gene whose expression is inversely correlated to metastatic potential [42-45]. Vitamin D-mediated suppression of MMP-9 activity and increase in tissue inhibitor of metalloproteinase-1 (TIMP-1) also decrease the invasive potential of PCa cells [46].

$1,25(\mathrm{OH}) 2 \mathrm{D}_{3}$ inhibits the proliferation of endothelial cells and reduces vascular endothelial growth factor (VEGF)-induced endothelial cell growth and elongation. VEGF is a key mediator involved in positive regulation of the formation of new vessels [47]. In addition, vitamin D modulated bone resorption also plays an important role in metastasis in PCa and BCa cells [48]

\section{Anti-inflammatory Action}

Chronic inflammation, triggered by a variety of stimuli such as injury, infection, carcinogens, autoimmune disease, the development of tumors, hormonal factors and so forth, has been recognized as a risk factor for cancer development. Cancer-related inflammation is characterized by the presence of inflammatory cells at the tumor sites and over-expression of inflammatory mediators such as cytokines, chemokines, prostaglandins (PGs) and reactive oxygen and nitrogen species in tumor tissue. Many of these proinflammatory mediators activate angiogenic switches usually under the control of vascular endothelial growth factor (VEGF) and thereby promote tumor progression, metastasis, and invasion [49-51].

Vitamin D regulation of gene expression leads to the inhibition of the synthesis and biologic actions of prostaglandins (PGs) by inhibiting the expression of gene for the enzyme cyclooxygenase-2 and increasing the synthesis of catabolic enzyme 15-hyroxyprostaglandin dehydrogenase [52]. It also suppresses the activation and signaling of nuclear factor kappa $\mathrm{B}(\mathrm{NF} \kappa \mathrm{B})$, a transcription factor that regulates the expression of genes involved in inflammatory and immune responses and cellular proliferation and is believed to play a key role in the process leading from inflammation to carcinogenesis $[53,54]$.

$1,25(\mathrm{OH}) 2 \mathrm{D}_{3}$ has been reported to increase the expression of MAP kinase phosphatase MKP5, a member of the dual specificity MKP family of enzymes that dephosphorylate and thereby inactivate, MAPKs in normal human prostate epithelial cells. This action leads to downstream anti-inflammatory responses by causing the dephosphorylation and inactivation of the p38 stressinduced kinase, resulting in a decrease in the production of proinflammatory cytokines such as interleukin-6 (IL-6) [55].

\section{Role of vitamin D in Cancer Treatment}

$1,25(\mathrm{OH}) 2 \mathrm{D}_{3}$ deficiency has, definitely, a role to play in the causation, growth and spread of the tumour cells but its supplementation has been reported to increase the efficiency of different treatment modalities used for cancer. $1,25(\mathrm{OH}) 2 \mathrm{D}_{3}$ has been demonstrated to enhance the sensitivity of PCa cells 


\section{Cancer Therapy \& Oncology International Journal}

to ionizing radiation significantly by selectively suppressing radiation-mediated RelB activation and via suppression of the NFkB pathway [56]. There is also considerable evidence that vitamin $\mathrm{D}$ potentiates the antitumor activity of a wide variety of cytotoxic chemotherapy agents. In addition, the induction of p73 by $1,25(\mathrm{OH}) 2 \mathrm{D}_{3}$ seems to contribute to the synergistic activity of vitamin D and platinum analogues and some antimetabolites [57]. Vitamin D status may have a significant bearing in cancer outcome also as higher mortality in patients with colorectal carcinoma was found to be associated with groups having lower vitamin D levels [58]. Chemotherapy for colorectal rectal carcinoma has been reported to induce a state of vitamin D insufficiency or deficiency [59]. The role of vitamin $D$ in preventing adverse effects of chemotherapy is controversial and is an area of interest for further research $[60,61]$.

Treatment with vitamin D has been found to increase radiosensitization of tumour cells as reported by some recent studies. In a study on non small cell lung carcinoma, it was found that vitamin D radiosensitized A549 cells by significantly decreasing the cell colony formation ability by producing enhanced G2/M cell cycle arrest and promoting apoptosis [62]. Similarly increased radiosensitization has been reported in prostate carcinoma cells with vitamin D or vitamin D analogue supplementation $[63,64]$. $1,25(\mathrm{OH}) 2 \mathrm{D}_{3}$ has been reported to be effective against adverse effects associated with radiotherapy. In a recent report, vitamin D deficiency has been found to be associated with increased severity of radiation-induced acute proctitis in cancer patients [65].

\section{Conclusion}

Besides putting forward so many mechanisms for anti-cancer property of vitamin D, the effects of vitamin D on carcinogenesis or cancer progression remain incompletely understood. However, a great body of information about the association between vitamin $\mathrm{D}$ deficiency and increased cancer risk, together with the known benefits of maintaining adequate $25(\mathrm{OH}) \mathrm{D}_{3}$ serum levels for cancer prevention, treatment and improving the efficiency of different therapeutic modalities in the oncology field, warrant further research regarding this natural antineoplastic hormone. Recent research has focused on the use and invent of vitamin D analogs that have potential for more potent anti-proliferative effects on cancer cells with fewer hypercalcemic side effects.

\section{Conflict of Interest}

None.

\section{References}

1. Masuda S, Jones G (2006) Promise of vitamin D analogues in the treatment of hyperproliferative conditions. Mol Cancer Ther 5(4): 797-808.

2. Holick MF (2011) Vitamin D: Evolutionary, Physiological and Health Perspectives. Curr Drug Targets 12(1): 4-18.

3. Tiwari P, Sharma N (2017) Role of Vitamin D in Various Illnesses: A Review. J Pharma Care Health Sys 4: 176.
4. Basit S (2013) Vitamin D in health and disease: a literature review. Br J Biomed Sc 70(4): 161-172.

5. Jones G, Strugnell SA, DeLuca HF (1998) Current understanding of the molecular actions of vitamin D. Physiol Rev 78(4): 1193-1231.

6. Prosser DE, Jones G (2004) Enzymes involved in the activation and inactivation of vitamin D. Trends Biochem Sci 29(12): 664-673.

7. Cheng JB, Levine MA, Bell NH, Mangelsdorf DJ, Russell DW (2004) Genetic evidence that the human CYP2R1 enzyme is a key vitamin D 25-hydroxylase. Proc Natl Acad Sci USA 101(20): 7711-7715.

8. Yamamoto K, Uchida E, Urushino N, Sakaki T, Kagawa N, et al. (2005) Identification of the amino acid residue of CYP27B1 responsible for binding of 25-hydroxyvitamin D3 whose mutation causes vitamin D-dependent rickets type 1. J Biol Chem 280(34): 30511-30516.

9. Panda DK, Miao D, Bolivar I, Li J, Huo R, et al. (2004) Inactivation of the 25-hydroxyvitamin D 1a-hydroxylase and vitamin D receptor demonstrates independent and interdependent effects of calcium and vitamin D on skeletal and mineral homeostasis. J Biol Chem 279(16): 16754-16766.

10. Armbrecht HJ, Hodam TL, Boltz MA (2003) Hormonal regulation of 25-hydroxyvitamin D3-1 $\alpha$-hydroxylase and 24-hydroxylase gene transcription in opossum kidney cells. Arch Biochem Biophys 409(2): 298-304.

11. Quarles LD (2003) FGF23, PHEX, and MEPE regulation of phosphate homeostasis and skeletal mineralization. Am J Physiol Endocrinol Metab 285(1): E1-9.

12. DeLuca HF (2004) Overview of general physiologic features and functions of vitamin D. Am J Clin Nutr 80(suppl): 1689S-1696S.

13. Binkley N, Krueger D, Cowgill CS, Plum L, Lake E, et al. (2004) Assay variation confounds the diagnosis of hypovitaminosis D: a call for standardization. J Clin Endocrinol Metab 89(7): 3152-3157.

14. Hollis BW (2010) Assessment and Interpretation of Circulating 25-Hydroxyvitamin D and 1,25-Dihydroxyvitamin D in the Clinical Environment. Endocrinol Metab Clin North Am 39(2): 271-286.

15. Holick MF (2003) Vitamin D: A millennium perspective. J Cell Biochem 88(2): 296-307.

16. Tripkovic L, Lambert H, Hart K, Smith CP, Bucca G, et al. (2012) Comparison of vitamin $\mathrm{D}_{2}$ and vitamin $\mathrm{D}_{3}$ supplementation in raising serum 25-hydroxyvitamin D status: a systematic review and metaanalysis. Am J Clin Nutr 95(6): 1357-1364.

17. Leventis P, Kiely PD (2009) The tolerability and biochemical effects of high-dose bolus vitamin $\mathrm{D}_{2}$ and $\mathrm{D}_{3}$ supplementation in patients with vitamin D insufficiency. Scand J Rheumatol 38(2): 149-153.

18. Heaney RP, Recker RR, Grote J, Horst RL, Armas LAG (2011) Vitamin $D_{3}$ is more potent than vitamin D(2) in humans. J Clin Endocrinol Metab 96(3): E447-E452.

19. Holick MF (2007) Vitamin D deficiency. N Engl J Med 357: 266-281.

20. Lipkin M, Newmark HL (1999) Vitamin D, calcium and prevention of breast cancer: a review. J Am Coll Nutr 18 (5 suppl): 392S-397S.

21. Guyton KZ, Kensler TW, Posner GH (2001) Cancer chemoprevention using natural vitamin D and synthetic analogs. Annu Rev Pharmacol Toxicol 41: 421-442.

22. Hansen CM, Binderup L, Hamberg KJ, Carlberg C (2001) Vitamin D and cancer: effects of $1,25(\mathrm{OH}) 2 \mathrm{D} 3$ and its analogs. on growth control and tumorigenesis. Front Biosci 6: D820-D848.

23. Grant WB (2002) An estimate of premature cancer mortality in the US because of inadequate doses of solar ultraviolet-B radiation. Cancer 94(6): 1867-1875. 


\section{Cancer Therapy \& Oncology International Journal}

24. Giovannucci E (2009) Vitamin D and cancer incidence in the Harvard cohorts. Ann Epidemiol 19(2): 84-88.

25. Kostner K, Denzer N, Muller CS, Klein R, Tilgen W, et al. (2009) The relevance of vitamin D receptor (VDR) gene polymorphisms for cancer: a review of the literature. Anticancer Res 29(9): 3511-3536.

26. Matthews D, LaPorta E, Zinser GM, Narvaez CJ, Welsh J (2010) Genomic vitamin D signaling in breast cancer: Insights from animal models and human cells. J Steroid Biochem Mol Biol 121(1-2): 362-367.

27. Vanoirbeek E, Krishnan AV, Eelen G, Verlinden L, Bouillon R, et al. (2011) The Anti-Cancer and Anti-Inflammatory Actions of 1,25(OH) $\mathrm{D}_{3}$. Best Pract Res Clin Endocrinol Metab 25(4): 593-604.

28. Krishnan AV, Trump DL, Johnson CS, Feldman D (2010) The role of vitamin D in cancer prevention and treatment. Endocrinol Metab Clin North Am 39(2): 401-418.

29. Bouillon R, Eelen G, Verlinden L, Mathieu C, Carmeliet G, et al. (2006) Vitamin D and cancer. J Steroid Biochem Mol Biol 102(1-5): 156-162.

30. Yang ES, Burnstein KL (2003) Vitamin D inhibits G1 to S progression in LNCaP prostate cancer cells through p27Kip1 stabilization and Cdk2 mislocalization to the cytoplasm. J Biol Chem 278(47): 46862-46868.

31. Deeb KK, Trump DL, Johnson CS (2007) Vitamin D signalling pathways in cancer: potential for anticancer therapeutics. Nat Rev Cancer 7(9): 684-700.

32. Wang X, Gocek E, Liu CG, Studzinski GP (2009) MicroRNAs181 regulate the expression of p27Kip1 in human myeloid leukemia cells induced to differentiate by 1,25-dihydroxyvitamin D3. Cell Cycle 8(5): 736-741.

33. Thorne JL, Maguire O, Doig CL, Battaglia S, Fehr L, et al. (2011) Epigenetic control of a VDR-governed feed-forward loop that regulates p21(waf1/cip1) expression and function in non-malignant prostate cells. Nucleic Acids Res 39(6): 2045-2056.

34. Kizildag S, Ates H, Kizildag S (2009) Treatment of K562 cells with 1,25-dihydroxyvitamin $\mathrm{D}(3)$ induces distinct alterations in the expression of apoptosis-related genes BCL2, BAX, BCL(XL), and p21. Ann Hematol 89(1): 1-7.

35. Boyle BJ, Zhao XY, Cohen P, Feldman D (2001) Insulin-like growth factor binding protein-3 mediates 1 alpha, 25-dihydroxyvitamin $\mathrm{d}(3)$ growth inhibition in the LNCaP prostate cancer cell line through p21/ WAF1. J Urol 165(4): 319-324.

36. Zheng Y, Trivedi T, Lin RCY, Fong-Yee C, Nolte R, et al. (2017) Loss of the vitamin $D$ receptor in human breast and prostate cancers strongly induces cell apoptosis through downregulation of Wnt/ $\beta$-catenin signaling. Bone Res 5: 17023

37. Ylikomi T, Laaksi I, Lou YR, Martikainen P, Miettinen S, et al. (2002) Antiproliferative action of vitamin D. Vitam Horm 64: 357-406.

38. Park WH, Seol JG, Kim ES, Hyun JM, Jung CW, et al. (2000) Induction of apoptosis by vitamin D3 analogue EB1089 in NCI-H929 myeloma cells via activation of caspase 3 and p38 MAP kinase. Br J Haematol 109(3) $576-83$

39. Posner GH, Crawford KR, Peleg S, Welsh J, Romu S, et al. (2001) A non-calcemic sulfone version of the vitamin $D(3)$ analogue seocalcitol (EB 1089): chemical synthesis, biological evaluation and potency enhancement of the anticancer drug adriamycin. Bioorg Med Chem 9(9): 2365-2371.

40. Sundaram S, Sea A, Feldman S, Strawbridge R, Hoopes PJ, et al. (2003) The combination of a potent vitamin D3 analog, EB 1089, with ionizing radiation reduces tumor growth and induces apoptosis of MCF- 7 breast tumor xenografts in nude mice. Clin Cancer Res 9(6): 2350-2356.

41. Nakagawa K, Kawaura A, Kato S, Kato S, Takeda E, et al. (2005) 1 alpha,25-Dihydroxyvitamin $\mathrm{D}(3)$ is a preventive factor in the metastasis of lung cancer. Carcinogenesis 26(2): 429-440.
42. Koli K, Keski-Oja J (2000) 1alpha,25-dihydroxyvitamin D3 and its analogues down-regulate cell invasion-associated proteases in cultured malignant cells. Cell Growth Differ 11(4): 221-229.

43. Bao BY, Yao J, Lee YF (2006) 1alpha,25-dihydroxyvitamin D3 suppresses interleukin-8-mediated prostate cancer cell angiogenesis. Carcinogenesis 27(9): 1883-1893.

44. Abdulghani J, Gu L, Dagvadorj A, Lutz J, Leiby B, et al. (2008) Stat3 promotes metastatic progression of prostate cancer. Am J Pathol 172(6): 1717-1728.

45. Grant WB (2008) Vitamin D may reduce prostate cancer metastasis by several mechanisms including blocking Stat3. Am J Pathol 173(5): 1589-1590.

46. Bao BY, Yeh SD, Lee YF (2006) 1alpha,25-dihydroxyvitamin D3 inhibits prostate cancer cell invasion via modulation of selective proteases. Carcinogenesis 27(1): 32-42.

47. Furigay P, Swamy N (2004) Anti-endothelial properties of 1,25-dihydroxy-3-epi-vitamin D3, a natural metabolite of calcitriol. J Steroid Biochem Mol Biol 89-90(1-5): 427-431.

48. Zheng Y, Zhou H, Brennan K, Blair JM, Modzelewski JRK, et al. (2007) Inhibition of bone resorption, rather than direct cytotoxicity, mediates the anti-tumour actions of ibandronate and osteoprotegerin in a murine model of breast cancer bone metastasis. Bone 40(2): 471-478.

49. Allavena P, Garlanda C, Borrello MG, Sica A, Mantovani A (2008) Pathways connecting inflammation and cancer. Curr Opin Genet Dev 18(1): 3-10.

50. De Marzo AM, Platz EA, Sutcliffe S, Xu J, Grönberg H, et al. (2007) Inflammation in prostate carcinogenesis. Nat Rev Cancer 7(4): 256269.

51. Mantovani A, Allavena P, Sica A, Balkwill F (2008) Cancer-related inflammation. Nature 454(7203): 436-444.

52. Moreno J, Krishnan AV, Swami S, Nonn L, Peehl DM, (2005) Regulation of prostaglandin metabolism by calcitriol attenuates growth stimulation in prostate cancer cells. Cancer Res 65(17): 7917-7925.

53. McCarty MF (2004) Targeting multiple signaling pathways as a strategy for managing prostate cancer: multifocal signal modulation therapy. Integr Cancer Ther 3(4): 349-380.

54. Maeda S, Omata M (2008) Inflammation and cancer: role of nuclear factor-kappa B activation. Cancer Sci 99(5): 836-842.

55. Nonn L, Peng L, Feldman D, Peehl DM (2006) Inhibition of p38 by vitamin D reduces interleukin-6 production in normal prostate cells via mitogen-activated protein kinase phosphatase 5: implications for prostate cancer prevention by vitamin D. Cancer Res 66(8): 45164524.

56. Xu Y, Fang F, St Clair DK, Josson S, Sompol P, Spasojevic I, et al (2007) Suppression of RelB-mediated manganese superoxide dismutase expression reveals a primary mechanism for radiosensitization effect of 1alpha,25- dihydroxyvitamin $\mathrm{D}(3)$ in prostate cancer cells. Mol Cancer Ther 6(7): 2048-2056.

57. Ma Y, Yu WD, Hershberger PA, Flynn G, Kong R, et al. (2008) 1alpha,25Dihydroxyvitamin D3 potentiates cisplatin antitumor activity by p73 induction in a squamous cell carcinoma model. Mol Cancer Ther 7(9): 3047-3055.

58. Ng K, Meyerhardt JA, Wu K, Feskanich D, Hollis BW, et al. (2008) Circulating 25-hydroxyvitamin d levels and survival in patients with colorectal cancer. J Clin Oncol 26(18): 2984-2991.

59. Fakih MG, Trump DL, Johnson CS, Tian L, Muindi J, et al. (2009) Chemotherapy is linked to severe vitamin $D$ deficiency in patients with colorectal cancer. Int J Colorectal Dis 24(2): 219-224. 


\section{Cancer Therapy \& Oncology International Journal}

60. Fink M (2011) Vitamin D deficiency is a cofactor of chemotherapyinduced mucocutaneous toxicity and dysgeusia. J Clin Oncol 29(4) e81-82.

61. Kitchen D, Hughes B, Gill I, O’Brien M, Rumbles S, et al. (2012) The relationship between vitamin $\mathrm{D}$ and chemotherapy-induced toxicity a pilot study. Br J Cancer 107(1): 158-160.

62. Wang Z , Liu J , Si S , Xu B , WangY, Ren Y, et al (2017) Vitamin D improves the sensitization of lung cancer to radiotherapy. Int J Clin Exp Med 10(3): 4921-4928.

63. Dunlap N, Schwartz GG, Eads D, Cramer SD, Sherk AB, et al. (2003) 1alpha, 25-dihydroxyvitamin D(3) (calcitriol) and its analogue, 19-nor- 1alpha, 25(OH)(2)D(2), potentiate the effects of ionising radiation on human prostate cancer cells. Br J Cancer 89(4): 746-753.

64. Ma Y, Trump DL, Johnson CS (2010) Vitamin D in combination cancer treatment. J Cancer 1: 101-107.

65. Ghorbanzadeh-Moghaddam A, Gholamrezaei A, Hemati S (2015) Vitamin D deficiency is associated with the severity of radiationinduced proctitis in cancer patients. Int J Radiat Oncol Biol Phys 92(3): 613-618.

66. Kennel KA, Drake MT, Hurley DL (2010) Vitamin D Deficiency in Adults: When to Test and How to Treat. Mayo Clin Proc 85(8): 752-758.

\section{Your next submission with Juniper Publishers} will reach you the below assets

- Quality Editorial service

- Swift Peer Review

- Reprints availability

- E-prints Service

- Manuscript Podcast for convenient understanding

- Global attainment for your research

- Manuscript accessibility in different formats

( Pdf, E-pub, Full Text, Audio)

- Unceasing customer service

Track the below URL for one-step submission https://juniperpublishers.com/online-submission.php 